\title{
PENGARUH MODEL PEMBELAJARAN KOOPERATIF TIPE TPS BERBANTUAN PETA KONSEP TERHADAP PENGUASAAN KOMPETENSI PENGETAHUAN IPA SISWA KELAS IV
}

\author{
I Made Citra Anggara1,*, I Ketut Ardana², I Wayan Darsana3 \\ 1 Jurusan Pendidikan Guru Sekolah Dasar Universitas Pendidikan Ganesha \\ 2 Jurusan Pendidikan Guru Sekolah Dasar Universitas Pendidikan Ganesha \\ 2 Jurusan Pendidikan Guru Sekolah Dasar Universitas Pendidikan Ganesha
}

\begin{abstract}
Abstrak
Penelitian ini bertujuan untuk mengetahui perbedaan kompetensi pengetahuan IPA antara kelompok siswa yang dibelajarkan melalui model pembelajaran kooperatif tipe TPS berbantuan peta konsep dengan kelompok siswa yang dibelajarkan melalui pembelajaran konvensional pada siswa kelas IV SD Negeri di Gugus Letkol Wisnu Denpasar Utara. Populasi penelitian adalah siswa kelas IV SD Negeri di Gugus Letkol Wisnu. Sampel penelitian adalah siswa kelas IVA SD Negeri 1 Peguyangan sebagai kelompok eksperimen dan siswa kelas IVB SD Negeri 1 Peguyangan sebagai kelompok kontrol. Pengumpulan data dilakukan dengan metode tes (tes objektif). Data dianalisis menggunakan analisis uji-t. Hasil analisis diperoleh thitung $=6,229>$ tabel $=$ 2,000 (dk 83 taraf signifikansi 5\%), sehingga $\mathrm{H}_{0}$ ditolak dan $\mathrm{H}_{\mathrm{a}}$ diterima. Rerata kompetensi pengetahuan IPA pada kelompok eksperimen 84,10 dan kelompok kontrol 73,20. Dapat disimpulkan bahwa model pembelajaran kooperatif tipe TPS berbantuan peta konsep berpengaruh terhadap kompetensi pengetahuan IPA siswa kelas IV SD Negeri di Gugus Letkol Wisnu Kecamatan Denpasar Utara.
\end{abstract}

\author{
Keywords: \\ Kooperatif tipe TPS, Peta \\ konsep, Kompetensi \\ pengetahuan IPA
}

\section{PENDAHULUAN}

Sekolah Dasar (SD) merupakan salah satu jenjang pendidikan formal. SD merupakan jenjang yang amat penting bagi siswa, karena pada jenjang ini siswa memperoleh kemampuan dasar untuk mengembangkan potensinya saat ini dan pada jenjang pendidikan yang akan ditempuh selanjutnya. Keberhasilan dan kegagalan siswa selama mengikuti pembelajaran di SD akan sangat menentukan masa depannya pada jenjang pendidikan yang lebih tinggi lagi.

Seperti yang kita ketahui kurikulum yang digunakan saat ini di sekolah dasar adalah kurikulum 2013. Dalam kurikulum 2013 pendekatan saintifik merupakan salah satu pendekatan pembelajaran yang dianjurkan.Denganmengaitkan isi pelajaran dengan mata pelajaran lain menggunakan pendekatan saintifik maka pelajaran lebih bermakna, karena siswa mengetahui pelajaran yang diperoleh di kelas akan bermanfaat dalam kehidupannya sehari-hari. Dalam proses pembelajarannya saintifik lebih menekankan pada pentingnya pembentukan karakter siswa di sekolah, terutama pada pendidikan dasar. Dalam pembelajaran pendekatan saintifik terdiri atas lima pengalaman belajar, yaitu mengamati, menanya, mengumpulkan informasi, mengasosiasi, dan mengkomunikasikan.Kurikulum 2013 dirancang untuk memberikan pengalaman belajar seluas-luasnya bagi peserta didik dalam mengembangkan pengetahuannya.

Pendekatan pembelajaran saintifik ini diterapkan untuk seluruh kelas di sekolah dasar (SD). Pembelajaran dengan pendekatan tematik ini mencakup seluruh kompetensi mata pelajaran salah satunya yaitu Ilmu Pengetahuan Alam (IPA). Pembelajaran Ilmu Pengetahuan Alam (IPA) merupakan ilmu yang mempelajari keadaan alam serta gejala yang timbul sebagai satu cara untuk menjawab keraguan terhadap lingkungan sekitar dunia alami yang dipelajari yang terkandung didalamnya (Sapitri, 2015). IPA sebagai salah satu mata pelajaran di SD yang dinilai sangat memegang peran penting, karena IPA merupakan bagian dari kehidupan manusia dari sejak manusia itu mengenal dirinya sendiri hingga

\footnotetext{
* Corresponding author.

E-mail Addresses: Citraanggara01@Gmail.com (I Made Citra Anggara),ketut_ardana55@yahoo.com (I Ketut Ardana), w darsana@ymail.com

(I Wayan Darsana)
} 
mengenal alam sekitar. Dengan kata lain IPA adalah ilmu pengetahuan yang mempelajari mengenai manusia dan lingkungannya.

Idealnya, proses pembelajaran IPA di sekolah dasar memberikan kesempatan kepada siswa untuk berperan aktif dalam proses pembelajaran melalui kegiatan belajar secara nyata yang dapat memupuk rasa ingin tahu dan sikap ilmiah siswa. Sikap ilmiah siswa dalam proses pembelajaran IPA dapat dikembangkan melalui kegiatan diskusi, percobaan, simulasi, atau kegiatan proyek di lapangan (Susanto,2013:169). Pembelajaran IPA yang menarik bukan hanya pengetahuan berupa fakta, konsep, dan teori, tetapi pembelajaran yang bermakna sehinga merangsang keingintahuan siswa terhadap pembelajaran dan lingkungan nya.

Tetapi, hal yang diharapkan di kurikulum 2013 tidak sesuai dengan kenyataan terbukti dari hasil observasi pada tanggal 19 januari di gugus letkol wisnu ,berdasarkan informasi dari masing-masing wali kelas IV di gugus lelkol wisnu dengan jumlah 9 wali kelas, terkait nilai ulangan akhir semester I, menunjukkan bahwa sebagian besar nilai pengetahuan siswa pada muatan pembelajaran IPA masih belum mampu menunjukkan hasil belajar yang baik terbukti 61\% siswa yang mendapatkan nilai dibawah standar. Hal tersebut diakibatkan karena kurangnya partisipasi dan minat siswa dalam mengikuti pembelajaran IPA kurang sehingga materi yang diberikan oleh guru tidak dapat dipahami dengan baik. Sejalan dengan penelitian yang dilakukan oleh Susanti (2017) menemukan bahwa masih banyak siswa yang tidak mengerti dengan materi yang telah disampaikan. Hal ini diakibatkab oleh kebiasaan guru dalam mengajar, guru sering menggunakan metode Dairect Interaction (pembelajaran langsung) dengan model ceramah, tanya jawab, dan penyampaiaan informasi.Sehingga guru lebih monoton disaat proses pembelajaran berlangsung. Keadaan seperti ini, mengakibatkan siswa lebih banyak mendengarkan apa yang di jelaskan.

Dalam menyikapi permasalahan tersebut peran guru sangatlah penting dalam merancang pembelajaran agar pembelajaran menjadi menarik, aktif, dan menyenangkan. Salah satu upaya yang bisa digunakan oleh guru dengan menggunakan model pembelajaran kooperatif tipe think pair share (TPS).

Trianto $(2015 ; 129)$ menjelaskan model pembelajaran Kooperatif tipe Think Pair Share adalah jenis pembelajaran kooperatif untuk mempengaruhi pola interaksi siswa Strategi Think Pair Share ini berkembang dari penelitian belajar. Menurut Kurniasih dan Berlin (2016:58) Model TPS merupakan suatu cara yang efektif untuk membuat variasi suasana pola diskusi kelas. Dengan asumsi bahwa semua resitasi atau diskusi membutuhkan pengaturan untuk mengendalikan kelas secara keseluruhan, dan prosedur yang digunakan dalam Think Pair Share dapat memberi siswa lebih banyak waktu berpikir, untuk merespon dan saling membantu. Model pembelajaran Think Pair Share menggunakan metode diskusi berpasangan yang dilanjutkan dengan diskusi pleno. Dengan model pembelajaran ini siswa dilatih bagaimana mengutarakan pendapat dan siswa juga belajar menghargai pendapat orang lain dengan tetap mengacu pada materi atau tujuan pembelajaran.

Sintaks model pembelajaran Think Pair Share. Ketiga tahapan tersebut yaitu sebagai berikut.

Langkah 1: Berpikir (thinking)

Guru mengajukan suatu pertanyaan atau masalah yang dikaitkan dengan pelajaran dan meminta

siswa menggunakan waktu beberapa menit untuk berpikir sendiri jawaban atau masalah.

Langkah 2: Berpasangan (pairing)

Guru meminta siswa untuk berpasangan dan mendiskusikan apa yang telah mereka peroleh. Interaksi selama waktu yang disediakan dapat menyatukan jawaban jika suatu pertanyaan yang diajukan menyatukan gagasan apabila suatu masalah khusus yang diidentifikasi.

Langkah 3: Berbagi (sharing)

Pada langkah terakhir, guru meminta setiap pasangan untuk berbagi dengan keseluruhan kelas yang telah mereka bicarakan. Hal ini efektif untuk berkeliling ruangan dari pasangan ke pasangan dan melanjutkan sampai sekitar sebagian pasangan mendapat kesempatan untuk melaporkan.

Media pembelajaran adalah segala sesuatu yang dapat digunakan untuk menyalurkan pesan (bahan pembelajaran) sehingga dapat merangsang perhatian, minat, pikiran, dan perasaan belajar siswa dalam kegiatan belajar untuk mencapai tujuan pembelajaran tertentu salah satu media pembelajaran adalah peta konsep.

Peta konsep adalah suatu alat pengajaran yang di rekomendasikan oleh Ausubel, untuk mengkaitan bahan-bahan pembelajaran baru dengan pengetahuan awal. Peta konsep atau pemetaan konsep sebagai berikut : Inovasi baru yang penting untuk membantu anak menghasilkan pembelajaran bermakna dalam kelas(Samatowa,2016:20). Sri Artini (2014) menjelaskan peta konsep menyediakan bantuan visual konkret untuk membantu mengorganisasikan informasi sebelum informasi tersebut dipelajari.Adapun yang dimagsud peta konsep adalah ilustrasi grafis konkret yang mengindikasikan bagaimana sebuah konsep tunggal dihubungkan ke konsep-konsep lain pada katagori yang sama. 
Ketertarikan untuk melakukan penelitian ini didukung oleh penelitian-penelitian serupa yang dilakukan oleh Tas, Palimbong dan Hasdin (2014) yang menemukan bahwa dengan model pembelajaran kooperatif tipe Think Pair Share dapat meningkatkan Prestasi belajar siswa pada mata pelajaran IPS di kelas IV SD Inpres Mayayap. Berdasarkan hasil penelitian menunjukkan bahwa aktivitas guru dan siswa mengalami peningkatan yang cukup berarti dari siklus I ke siklus II dan untuk analisis tes akhir tindakan dari siklus I ke siklus II terjadi peningkatan belajar klasikal sebesar 36\% yaitu dari 64\% pada siklus I menjadi 100\% pada siklus II. Selain itu Murda dan Purwanti (2017), menyatakan bahwa penerapan strategi pembelajaran Think Pair Share dapat meningkatkan kemampuan membaca intensif siswa. Tristiantari, Marhaeni \& Koyan (2013) juga menyarankan bahwa model pembelajaran ini hendaknya diperkenalkan dan dikembangkan agar peserta didik mampu meningkatkan keterampilan berpikir kreatifnya. Gunawan (2016) juga menyarankan penggunaan model pembelajaran Think Pair Sharek dapat membangkitkan interaksi siswa dengan penalaran dalam berpikir serta berdiskusi bersama teman kelompoknya yang didapatkan secara berpasangan dimana tujuannya untuk menjadikan siswa aktif dalam pembelajaran.

\section{METODE}

Penelitian ini dikategorikan ke dalam penelitian eksperimen semu (quasi experiment design) karena tidak semua variabel dan kondisi eksperimen dapat diatur dan dikontrol secara ketat. Penelitian ini bertujuan untuk menguji pengaruh variabel-variabel bebas diantaranya meliputi model pembelajaran problem solving yang diterapkan pada kelompok eksperimen dan pembelajaran konvensional yang diterapkan pada kelompok kontrol terhadap hasil belajar IPA siswa. Desain yang digunakan dalam penelitian ini adalah nonequivalent control group design (Sugiyono, 2016:79).

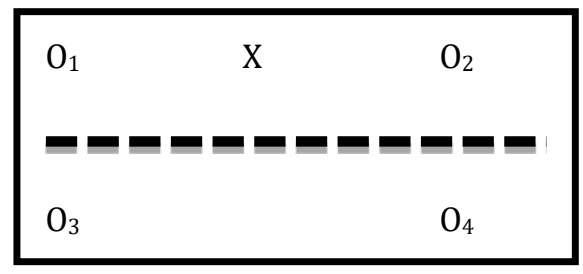

Gambar 1.

Gambar Penelitian Eksperimen Semu Menggunakan "Nonequivalent Control Group Design"

Populasi dalam penelitian ini adalah seluruh kelas IV SD Negeri di Gugus Letkol Wisnu Denpasar Utara, yang terdiri dari 7 (tujuh) sekolah, dengan seluruh siswa kelas IV sebanyak 340 siswa. Bila populasi besar, dan peneliti tidak mungkin mempelajari semua yang ada pada populasi, misalnya karena keterbatasan dana, tenaga, dan waktu, maka peneliti dapat menggunakan sampel yang diambil dari populasi itu. Sampel adalah bagian dari jumlah dan karakteristik yang dimiliki oleh populasi tersebut. Apa yang dipelajari dari sampel itu, kesimpulannya akan dapat diberlakukan untuk populasi. Untuk itu sampel yang diambil dari populasi harus betul-betul representatif (mewakili) (Sugiyono, 2016:118). Dapat dirangkum, sampel merupakan bagian dari populasi yang dapat mewakili populasi dalam penelitian. Penelitian ini dalam menentukan kelompok eksperimen dan kelompok kontrol dari populasi tersebut, peneliti menggunakan teknik random sampling. Langkah-langkah penentuan sampel sebagai berikut (Sugiyono, 2016:118). 1) dilakukan teknik pengambilan sampel dengan cara undian, sehingga semua anggota populasi memiliki kesempatan yang sama untuk dipilih menjadi sampel penelitian. Pada penelitian ini, kelas yang sudah terbentuk merupakan unit-unit populasi yang lebih kecil. Untuk mendapatkan dua kelas yang dijadikan kelompok eksperimen dan kelompok kontrol maka dilakukan pada kelas yang sudah terbentuk sehingga terpilih dua kelas yang representatif untuk dijadikan sampel penelitian, 2) setelah dua kelas terpilih melalui pengundian, maka dilakukan uji kesetaraan untuk mengetahui tingkat kesetaraan kedua kelas yang dijadikan kelompok eksperimen dan kelompok kontrol dengan menggunakan nilai kompetensi pengetahuan siswa pada tema sebelumnya. Data rerata dari kompetensi pengetahuan siswa pada tema sebelumnya dilakukan uji analisis dengan uji beda rerata antar kelompok kelas. Hasil belajar pengetahuan siswa dianalisis dengan uji beda (uji-t), varians homogen dengan $\mathrm{n}_{1} \neq \mathrm{n}_{2}$ untuk sampel yang tidak berkorelasi, 3) apabila semua kelas sudah setara maka dilakukan pemilihan kelas sebagai kelompok eksperimen dengan perlakuan model pembelajaran kooperatif tipe TPSberbantuan peta konsepdan kelompok kontrol menggunakan pembelajaran konvensional. Berdasarkan hasil perhitungan uji kesetaraan dan uji-t, maka diperoleh dua kelas yang dijadikan sampel 
penelitian. Sampel yang digunakan dalam penelitian ini terdiri dari 2 (dua) kelompok, yaitu kelas IVA di SD Negeri 1 peguyangan sebagai kelompok eksperimen yang berjumlah 40 siswa, dan kelas IVB di SD Negeri 1 Peguyangan sebagai kelompok kontrol yang berjumlah 45 siswa.

Langkah-langkah yang ditempuh dalam penelitian ini adalah 1) menentukan populasi penelitian, 2) menentukan sampel penelitian dengan teknik random sampling, 3) menyusun instrumen penelitian yang berupa tes objektif pilihan ganda biasa untuk mengukur kompetensi pengetahuan IPA siswa, 4) mengkonsultasikan instrumen penelitian dengan dosen pengampu mata kuliah IPA 5) melakukan uji coba instrumen, 6) melakukan analisis data untuk mendapatkan validitas, reliabilitas, daya beda, dan tingkat kesukaran, 7) menyiapkan rencana pelaksanaan pembelajaran (RPP) sesuai dengan model pembelajaran yang akan diterapkan, 8) memberikan perlakuan berupa pembelajaran dengan model pembelajaran kooperatif tipe TPSberbantuan peta konsep pada kelompok eksperimen dan pembelajaran konvensional pada kelompok kontrol, 9) memberikan post test pada semua kelas sampel untuk mendapatkan data berupa skor kompetensi pengetahuan IPA siswa, dan 10) melakukan analisis hasil penelitian untuk menguji hipotesis yang diajukan.

Data yang diperlukan dalam penelitian ini adalah data mengenai kompetensi pengetahuan IPA siswa kelas IV SD Gugus Letkol Wisnu Denpasar Utara Tahun Ajaran 2016/2017. Menurut pendapat Agung (2014:89) "Data adalah bahan mentah atau informasi, dapat berupa angka-angka dan kategorikategori mengenai objek tertentu". Metode pengumpulan data merupakan cara-cara yang dapat dilakukan untuk mengumpulkan data/informasi. Metode pengumpulan data yang digunakan dalam penelitian ini adalah menggunakan tes. Arifin (2014:118) menyatakan bahwa "Tes merupakan suatu teknik yang digunakan dalam melaksanakan kegiatan pengukuran, yang di dalamnya terdapat berbagai pertanyaan, pernyataan, atau serangkaian tugas yang harus dikerjakan oleh peserta didik untuk mengukur suatu aspek tertentu". Jenis tes yang digunakan yaitu tes objektif pilihan ganda biasa, yaitu terdiri atas suatu keterangan atau pemberitahuan tentang suatu pengertian yang belum lengkap. Untuk melengkapinya harus memilih satu dari beberapa kemungkinan jawaban yang telah disediakan. Kemungkinan jawaban terdiri atas satu jawaban yang benar yaitu kunci jawaban dan beberapa jawaban pengecoh (Suharsimi, 2015:183).

Alat ukur dalam penelitian biasanya dinamakan instrumen penelitian. Instrumen penelitian adalah suatu alat yang digunakan mengukur fenomena dan telah teruji validitas dan reliabilitasnya (Sugiyono, 2016:102). Instrumen dalam penelitian ini digunakan untuk mengukur kompetensi pengetahuan IPA siswa pada kelompok eksperimen dan kelompok kontrol yang diberikan perlakuan berbeda, yaitu kelas yang menggunakan model pembelajaran kooperatif tipe TPSberbantuan peta konsepdan kelas yang menggunakan pembelajaran konvensional. Tes yang diberikan kedua kelas tersebut pada akhir perlakuan akan digunakan untuk menguji kebenaran hipotesis penelitian.

Instrumen tes yang baik terlebih dahulu harus disusun dengan meminta masukan para ahli, hal ini dilakukan untuk mengetahui apakah tes yang disusun sudah mencerminkan materi yang disampaikan. Tes hasil belajar IPA siswa yang telah disusun kemudian diuji cobakan untuk mendapatkan gambaran secara empirik tentang kelayakan tes tersebut dipergunakan sebagai instrumen penelitian. Hasil uji coba dianalisis terlebih dahulu untuk mendapatkan validitas, reliabilitas, daya beda, dan tingkat kesukaran tes. Analisis perhitungan hasil uji coba instrumen menggunakan bantuan Microsoft Excel 2013 for Windows. Tujuan dari uji kualitas instrumen penelitian yaitu untuk dapat menentukan apakah suatu tes hasil belajar telah memiliki validitas atau daya ketepatan mengukur (Sudijono, 2013:163). "Tes hendaknya disusun sesuai dengan prinsip dan prosedur penyusunan tes" (Arifin, 2014:246). Jadi, validitas suatu instrumen adalah pengujian yang dilakukan dengan tujuan untuk melihat apakah tes tersebut valid (sahih) atau tidak serta bertujuan untuk mengukur ketepatan suatu alat ukur.Berdasarkan hasil uji coba instrumen, soal yang digunakan untuk mengukur kompetensi pengetahuan IPA siswa berjumlah 30 butir soal.

Untuk menguji apakah terdapat perbedaan kompetensi pengetahuan IPA siswa dengan model pembelajaran kooperatif tipe TPSberbantuan peta konsep terhadap kompetensi pengetahuan IPA siswa yang dibelajarkan dengan pembelajaran konvensional, maka data yang diperoleh dianalisis dengan menggunakan teknik analisis deskriptif dan uji-t. Statistik deskriptif adalah statistik yang berfungsi untuk mendeskripsikan atau memberi gambaran terhadap objek yang diteliti melalui data sampel atau populasi, tanpa melakukan analisis dan membuat kesimpulan yang berlaku untuk umum (Sugiyono, 2013:29). Teknik analisis statistik deskriptif dalam penelitian ini digunakan untuk mendeskripsikan data kompetensi pengetahuan IPA siswa yang dibelajarkan melalui model pembelajaran kooperatif tipe TPSberbantuan peta konsep dan kompetensi pengetahuan IPA siswa yang dibelajarkan melalui pembelajaran konvensional. Teknik analisis dengan data kuantitatif dapat menggunakan teknik statistik deskriptif diantaranya menentukan nilai rerata (mean), simpangan baku, dan varians.

Sebelum melaksanakan pengujian guna mendapatkan simpulan, maka data yang diperoleh harus terlebih dahulu diuji normalitas dan homogenitas variansnya. Uji normalitas dilakukan untuk mengetahui 
apakah sebaran frekuensi skor pada setiap variabel berdistribusi normal atau tidak. Chi Kuadrat $\left(X^{2}\right)$ satu sampel adalah teknik statistik yang digunakan untuk menguji hipotesis bila dalam populasi terdiri atas dua atau lebih kelas dimana data berbenuk nominal dan sampelnya besar (Sugiyono, 2013:107). Uji normalitas data dilakukan terhadap data post test kompetensi pengetahuan IPA siswa kelompok eksperimen maupun kelompok kontrol. Pengujian normalitas menggunakan uji Chi Kuadrat $\left(X^{2}\right)$ pada taraf signfikansi 5\% dan derajat kebebasan $(\mathrm{dk})=(\mathrm{k}-1)=6-1=5$. Kriteria pengujian adalah jika $X_{\text {hitung }}^{2} \leq$ $X_{\text {tabel }}^{2}$, maka data berdistribusi normal. Uji homogenitas varians dilakukan untuk mencari tingkat homogen (kesamaan) antara dua pihak yang diambil dari kelompok-kelompok terpisah satu populasi yaitu kelompok eksperimen dan kelompok kontrol. Uji homogenitas varians untuk kedua kelompok digunakan uji F (Fisher). Dengan kriteria pengujian $F_{\text {hitung }} \geq F_{\text {tabel }}$ maka sampel homogen. Pengujian ini dilakukan pada taraf signifikansi 5\% dengan derajat kebebasan (dk) untuk $n_{\text {pembilang }}-1$ dan derajat kebebasan ( $\mathrm{dk}$ ) untuk $n_{\text {penyebut }}-1$.

Teknik analisis data yang digunakan untuk menguji hipotesis dalam penelitian ini yaitu menggunakan uji-t dengan rumus polled varians dan $d b=n_{1}+n_{2}-2$. Uji-t ini digunakan karena sampel dalam penelitian ini tidak berkorelasi atau terpisah yang jumlah anggota sampelnya tidak sama tetapi memiliki varians yang homogen. Kriteria pengujian ini dengan taraf signifikansi $5 \%$ yang mengkomparasikan $t_{\text {hitung }}$ dengan $t_{\text {tabel }}$. Apabila $t_{\text {hitung }}>t_{\text {tabel }}$ maka terdapat perbedaan yang signifikan antara kedua variabel atau sampel ( $\mathrm{H}_{0}$ ditolak) (Sugiyono, 2013:138).

\section{HASIL DAN PEMBAHASAN}

Berdasarkan hasil perhitungan skor post test kompetensi pengetahuan IPA siswa pada kelompok eksperimen dan kelompok kontrol, diperoleh hasil analisis data statistik deskriptif yang disajikan pada tabel 1.

Tabel 1. Tabel Deskripsi Hasil Penelitian

\begin{tabular}{lcc}
\hline Statistik & Kelompok Eksperimen & $\begin{array}{c}\text { Kelompok } \\
\text { Kontrol }\end{array}$ \\
\hline Banyak Sampel & 40 & 45 \\
Skor Tertinggi & 96,00 & 90,00 \\
Skor Terendah & 70,00 & 56,00 \\
Rerata (mean) & 84,10 & 73,20 \\
Standar Deviasi & 6,92 & 8,52 \\
Varians & 47,89 & 72,66 \\
\hline
\end{tabular}

Pada tabel 1 menunjukkan bahwa kelompok eksperimen memperoleh Rerata (mean) lebih tinggi dibandingkan dengan kelompok kontrol yaitu dengan skor 84,10. Standar deviasi dari kelompok eksperimen adalah 6,92, maka dapat dikatakan bahwa skor dari kelompok eksperimen cenderung tinggi. Apabila divisualisasikan ke dalam bentuk diagram akan tampak seperti gambar 1 berikut.

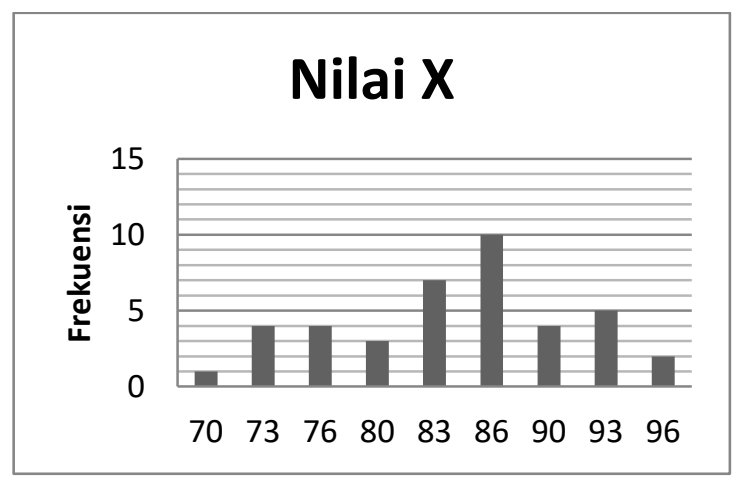

Gambar 2. Gambar Diagram Batang Distribusi Frekuensi Kompetensi Pengetahuan IPA Kelompok Eksperimen

Berdasarkan perhitungan yang dilakukan dengan mengikuti PAP Skala Lima, maka kompetensi pengetahuan IPA siswa setelah dibelajarkan dengan model pembelajaran kooperatif tipe TPSberbantuan 
peta konsep berada pada kategori baik, yaitu pada rentang skor 80 - 89 sebanyak 20 orang siswa atau $50 \%$.

Selanjutnya, skor rerata (mean) kelompok kontrol lebih rendah dari kelompok eksperimen yaitu 73,20, dengan standar deviasi 8,52, maka dapat dikatakan bahwa skor dari kelompok kontrol cenderung rendah. Apabila divisualisasikan ke dalam bentuk diagram akan tampak seperti gambar 2 berikut.

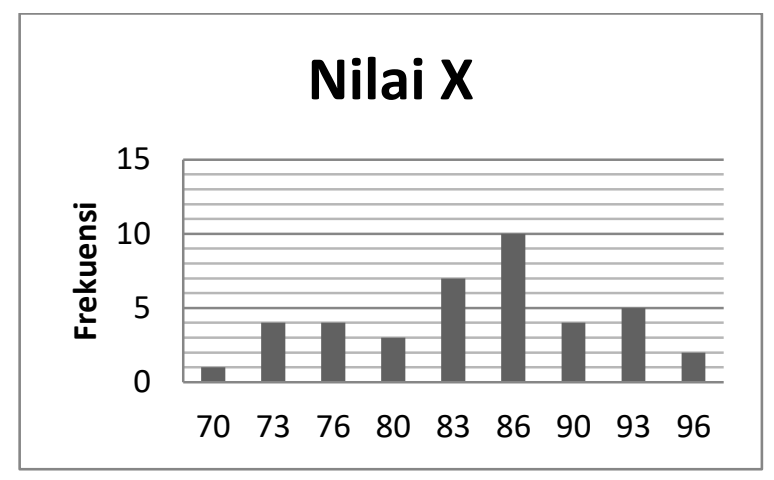

Gambar 3. Gambar Diagram Batang Distribusi Frekuensi Kompetensi Pengetahuan IPA Kelompok Kontrol

Berdasarkan perhitungan yang dilakukan dengan mengikuti PAP Skala Lima, maka kompetensi pengetahuan IPA siswa setelah dibelajarkan dengan pembelajaran konvensional berada pada kategori cukup, yaitu pada rentang skor 65 - 79 sebanyak 19 siswa atau 42,22\%.

Berdasarkan analisis yang dilakukan, maka diperoleh hasil perhitungan uji normalitas post test kelompok eksperimen yaitu $X_{\text {hitung }}^{2}=3,19$ dan $X_{\text {tabel }}^{2}=11,07$ pada taraf signifikansi $5 \%$ dan dk $=6-1=5$. Ini berarti bahwa $X_{\text {hitung }}^{2}<X_{\text {tabel }}^{2}$, maka data hasil post test kelompok eksperimen berdistribusi normal. Selanjutnya, hasil perhitungan uji normlitas kelompok kontrol diperoleh $X_{\text {hitung }}^{2}=3,62$ dan $X_{\text {tabel }}^{2}=11,07$ pada taraf signifikansi $5 \%$ dan $\mathrm{dk}=6-1=5$. Ini berarti bahwa $X_{\text {hitung }}^{2}<X_{\text {tabel }}^{2}$, maka data hasil post test kelompok kontrol berdistribusi normal.

Hasil uji homogenitas varians antara kelompok eksperimen dan kelompok kontrol dengan $d k_{\text {pembilang }}=45-1=44$ dan $d k_{\text {penyebut }}=40-1=39$ pada taraf signifikansi $5 \%$ diketahui $F_{\text {hitung }}=1,52$ dan $F_{\text {tabel }}=1,69$. Hasil ini berarti bahwa $F_{\text {hitung }}<F_{\text {tabel }}$, sehingga data post test siswa memiliki varians yang homogen.

Berdasarkan hasil perhitungan hipotesis dengan menggunakan uji-t diperoleh hasil analisis data seperti disajikan pada tabel 2 berikut.

Tabel 2. Tabel Hasil Uji Hipotesis

\begin{tabular}{lcccccc}
\hline \multicolumn{1}{c}{ Sampel } & $\mathrm{N}$ & Mean & $\mathrm{Dk}$ & $t_{\text {hitung }}$ & $t_{\text {tabel }}$ & Ket \\
\hline Eksperimen & 40 & 84,10 & \multirow{2}{*}{83} & 6,229 & 2,000 & $\mathrm{H}_{0}$ ditolak \\
Kontrol & 45 & 73,20 & & & & \\
\hline
\end{tabular}

Tabel 2 menunjukkan bahwa $t_{\text {hitung }}=6,229$, sedangkan $t_{\text {tabel }}=2,000$ dengan $\mathrm{dk}=45+40-2=83$ pada taraf signifikansi $5 \%$. Hal ini berarti nilai $t_{\text {hitung }}>t_{\text {tabel }}(6,229>1,989)$, maka $_{0}$ ditolak dan $\mathrm{H}_{\mathrm{a}}$ diterima. Ini berarti terdapat perbedaan yang signifikan kompetensi pengetahuan IPA siswa yang dibelajarkan dengan model pembelajaran kooperatif tipe TPSberbantuan peta konsep dengan siswa yang dibelajarkan melalui pembelajaran konvensional pada siswa kelas IV di SD Negeri Gugus Letkol Wisnu Denpasar Utara Tahun Ajaran 2016/2017.

\section{PEMBAHASAN}

Dengan diterapkannya model pembelajaran kooperatif tipe TPSberbantuan peta konsep pada siswa kelompok eksperimen dan pembelajaran konvensional pada siswa kelompok kontrol, tentunya untuk mengetahui perbedaan kompetensi pengetahuan dari penerapan model pembelajaran tersebut. Setalah kelompok eksperimen dan kelompok kontrol diberikan perlakuan, maka kedua kelas tersebut diberikan post test untuk mengetahui kompetensi pengetahuan IPA. Adapun hasil analisis data penelitian pada kedua kelas diperoleh bahwa rerata kompetensi pengetahuan IPA pada kelompok eksperimen 
adalah $\bar{X}=84,10$ dan kelompok kontrol adalah $\bar{X}=73,20$. Selanjutnya data hasil belajar IPA diuji menggunakan statistik uji-t dan diperoleh $t_{\text {hitung }}=6,229>t_{\text {tabel }}=2,000 \mathrm{Hal}$ ini berarti hipotesis alternatif yang menyatakan bahwa terdapat perbedaan yang signifikan kompetensi pengetahuan IPA antara siswa yang dibelajarkan dengan model pembelajaran kooperatif tipe TPSberbantuan peta konsep dengan siswa yang dibelajarkan dengan pembelajaran konvensional dengan taraf signifikansi 5\% diterima. Hal tersebut didukung juga adanya perbedaan nilai rerata kompetensi pengetahuan IPA antara kelompok eksperimen yaitu $\bar{X}=84,10$ dan $\bar{X}=73,20$ pada kelompok kontrol. Kompetensi pengetahuan siswa pada kelompok eksperimen lebih baik apabila dibandingkan dengan kompetensi pengetahuan siswa pada kelompok kontrol. Hal ini disebabkan oleh model pembelajaran kooperatif tipe TPS berbantuan peta konsep dapat menarik minat siswa dan memotivasi siswa belajar lebih aktif. Selain itu, think pair share merupakan sebuah model pembelajaran yang memberi siswa kesempatan untuk bekerja sendiri dan bekerja sama dengan orang lain. Dalam model pembelajaran ini memberi siswa lebih banyak waktu berpikir, untuk merespon dan saling membantu. Model pembelajaran ini dapat digabungkan dengan berbagai media seperti peta konsep, yaitu menyediakan bantuan visual konkret untuk membantu mengorganisasikan informasi sebelum informasi tersebut dipelajari. Adapun yang dimagsud peta konsep adalah ilustrasi grafis konkret yang mengindikasikan bagaimana sebuah konsep tunggal dihubungkan ke konsep-konsep lain pada katagori yang sama.

Hasil penelitian ini menguatkan beberapa hasil penelitian yang ditemukan belakangan ini, diantaranya penelitian yang dilakukan oleh Khamid (2014) bahwa ada peningkatan hasil belajar siswa kelas VI A SD Negeri Jetis 1 dengan model pembelajaran kooperatif tipe Think Pair Share. Hasil penelitian lain juga menunjukkan bahwa diperoleh peningkatan dalam pembelajaran PKn dengan model pembelajaran cooperative learning tipe think pair share pada siswa kelas V di SD Inpres Duyu (Darlin, 2015). Selain menguatkan hasil penelitian yang menerapkan pembelajaran kooperatif tipe Think Pair Share, hasil penelitian ini juga menguatkan hasil penelitian yang menerapkan pembelajaran berbantuan peta konsep. Dengan berbantuan peta konsep, terdapat perbedaan yang signifikan dalam hasil belajar IPS antara siswa yang mengikuti model accelerated learning berbasis peta konsep dan siswa yang mengikuti model pembelajaran konvensional (Suardipa, Lasmawan \& Suarni, 2013). Implementasi strategi think pair share (TPS) dalam pembelajaran IPA dengan menggunakan peta konsep dapat meningkatkan hasil belajar siswa kelas V SD Negeri 4 Tajun tahun ajaran 2012/2013 (Kardiasih, Suwatra \& Suarni, 2013).

\section{SIMPULAN DAN SARAN}

Berdasarkan hasil penelitian dan pembahasan, dapat disimpulkan sebagai berikut. Hasil penelitian analisis data post test menunjukkan bahwa rerata kompetensi pengetahuan IPA kelompok ekseperimen lebih tinggi daripada rerata kelompok kontrol $(84,10>73,20)$. Berdasarkan hasil analisis uji-t diperoleh $t_{\text {hitung }}$ sebesar 6,229 dan $t_{\text {tabel }}$ dengan $\mathrm{dk}=40+45-2=83$ pada taraf signifikansi $5 \%$ adalah 2,000 karena $t_{\text {hitung }}>t_{\text {tabel }}(6,229>2,000)$, maka $\mathrm{H}_{0}$ ditolak. Hal ini membuktikan bahwa terdapat perbedaan yang signifikan kompetensi pengetahuan IPA antara kelompok siswa yang dibelajarkan melalui model pembelajaran kooperatif tipe TPSberbantuan peta konsep dengan kelompok siswa yang dibelajarkan melalui pembelajaran konvensional.

Jadi dapat disimpulkan bahwa penerapan model pembelajaran kooperatif tipe TPSberbantuan peta konsep berpengaruh terhadap kompetensi pengetahuan IPA siswa kelas IV Gugus Letkol Wisnu Denpasar Utara Tahun Ajaran 2016/2017.

Dengan dilakukan penelitian ini, diharapkan guru dapat menambah wawasan dan pengetahuan tentang mengembangkan inovasi dalam merancang pembelajaran sesuai dengan kurikulum 2013 yang bertujuan untuk memperoleh kompetensi pengetahuan yang optimal. Dengan adanya kurikulum 2013, diharapkan guru mampu menerapkan pendekatan saintifik yang lebih optimal dipadukan dengan model pembelajaran kooperatif tipe TPSberbantuan peta konsep. Selain itu, dengan penerapan model pembelajaran kooperatif tipe TPSberbantuan peta konsep menjadi salah satu pendekatan yang diterapkan guru dalam kegiatan pembelajaran pada pembelajaran IPA yang dapat menarik minat dan menimbulkan rasa senang siswa dalam belajar. Dengan demikian dapat memberikan konstribusi yang baik terhadap kompetensi pengetahuan siswa.

Dengan diterapkannya model pembelajaran kooperatif tipe TPSberbantuan peta konsep pada pembelajaran IPA, siswa lebih aktif dan dapat mengembangkan kejasama kelompok dalam mengikuti pembelajaran serta mampu membangun pengetahuannya sendiri melalui pengalaman belajar untuk meningkatkan kompetensi pengetahuan siswa. Dengan demikian, siswa mampu mengaplikasikan apa yang telah diperoleh dalam pembelajaran yang nantinya akan diterapkan dalam kehidupan sehari-hari. 
Hasil penelitian ini dapat dijadikan pedoman bagi sekolah untuk menciptakan kondisi yang mampu memotivasi dan meningkatkan kualitas guru-guru dalam merancang pembelajaran yang inovatif dalam membelajarkan siswa sesuai dengan yang diharapkan dalam kurikulum 2013, sehingga dapat meningkatkan mutu dan kualitas sekolah menjadi lebih unggul dan inovatif.

\section{DAFTAR PUSTAKA}

Agung.A.A.Gede. 2014.Metodologi Penelitian Pendidikan. Malang: Aditya Media Publishing.

Arifin, Zainal. 2014. Evaluasi Pembelajaran Prinsip, Teknik, Prosedur. Bandung: PT Remaja Rosdakarya.

Arikunto Suharsimi. 2013. Dasar-dasar Evaalusi Pendidikan. Jakarta: Bumi Aksara.

Dantes, Nyoman. 2012. Metode Penelitian. Yogyakarta: CV Andi Offset.

Darlin. 2015. Penggunaan Model Cooperative Learning Tipe Think Pairs Hare Untuk Meningkatkan Hasil Belajar PKN Pada Siswa Kelas V SD Inpres Duyu. Jurnal Kreatif Tadulako Online. Volume 4, Nomor 7 (hlm. 257-264)

Daryanto. 2014. Pendekatan Pembelajaran Saintifik Kurikulum 2013. Yogyakarta: Gava Media

Ekadani Apriana, Igede Putu. 2014. “Pengaruh Model Pembelajaran Kooperatif Tipe Think Pair Share (TPS) Terhadap Motivasi Belajar PKN Siswa Kelas V Semester Genap Sd Di Gugus Iii Kecamatan Kubu Tahun Pelajaran 2014/2015”. Singaraja: Universitas Pendidikan Ganesha

Gunawan, Hendrik, Sri Utami \& Asmayani. 2016. Peningkatan Aktivitas Siswa Dalam Pembelajaran Pendidikan Kewarganegaraan Menggunakan Tipe Think Pair Share Kelas V. Jurnal Pendidikan dan Pembelajaran. Volume 5 Nomor 12

Huda, Miftahul. 2013. Model-Model Pengajaran dan Pembelajaran: Isu-Isu Metodis dan Paradigmatis. Yogyakarta: Pustaka Pelajar

Ibrahim, Muslimin, dkk. 2000. Pembelajaran Kooperatif. Surabaya: UNESHA Press.

Isjoni,H. 2011. Cooperative Learning. Bandung: Alfabeta

Kardiasih, Ayu, I Wyn Suwatra \& Ni Kt. Suarni. 2013. Implementasi Strategi Tps Dalam Pembelajaran Ipa Dengan Menggunakan Peta Konsep Sebagai Upaya Meningkatkan Aktivitas dan Hasil Belajar Siswa Kelas V. Jurnal Mimbar PGSD Universitas Pendidikan Ganesha. Volume 1, Nomor 1

Khamid. 2014. Peningkatan Hasil Belajar Matematika Melalui Think Pair Share pada Siswa Kelas VI SD Negeri Jetis 1 Yogyakarta. Jurnal Ilmiah Guru “COPE”. Nomor 02 (hlm. 8-15)

Koyan, I Wayan. 2007. Modul Telaah Kurikulum (Pengembangan Kurikulum Tingkat Satuan Pendidikan). Singaraja: Jurusan Pendidikan Dasar, FIP Universitas Pendidikan Ganesha.

Martiani, Ni Kdk. Dewi . 2014. “Pengaruh Metode Talking Stick Berbantuan Peta Konsep Terhadap Pemahaman Konsep IPA Siswa Kelas VSD ".( Tidak Diterbitkan). Mimbar PGSD UNDIKSHA.

Murda, Nyoman dan Putu Diah Purwanti. 2017. Penerapan Strategi PembelajaranThink Pair ShareUntuk Meningkatkan Kemampuan Membaca Intensif Siswa. International Journal of Elementary Education. Volume 1, Nomor 1 (hlm. 11-18)

Peraturan Menteri Pendidikan dan Kebudayaan Nasional Republik Indonesia Nomor103 Tahun 2014

Peraturan Menteri Pendidikan dan Kebudayaan Nasional Republik Indonesia Nomor 53 Tahun 2015

Sapitri, Nining. 2015. Penıngkatan Aktıvıtas Pembelajaran IPA Menggunakan Model Kooperatıf Tipe Think Pair Share Kelas VI SD.

Safiun \& La iru. 2012. Analisis Penerapan Pendekatan,Metode,Strategi dan Model-model Pembelajaran. DIY : Multi Presindo

Sani dan Kurniasih.2015.Ragam Pengembangan Model Pembelajaran Untuk Peningkatan Profesionalitas Guru.Kata Pena.

Setyosari.Punaji.2015. Metode Penelitian Pendidikan \& Pengembangan. Jakarta: Prenadamedia Group. 
Sri Arini, Ni Putu. 2014. "Pengaruh Strategi Pembelajaran Peta Konsep Berbantuan Media Gambar Terhadap Hasil Belajar IPA Siswa Kelas V Di Desa Panji Tahun Pelajaran 2013/2014”. Singaraja :Universitas Pendidikan Ganesha

Sri Arini, Ni Putu. 2014. "Pengaruh Strategi Pembelajaran Peta Konsep Berbantuan Media Gambar Terhadap Hasil Belajar IPA Siswa Kelas V Di Desa Panji Tahun Pelajaran 2013/2014”. (Tidak Diterbitkan). Universitas Pendidikan Ganesha.

Suardipa, I Putu, I Wayan Lasmawan \& Ni Ketut Suarni. 2013. Pengaruh Model Pembelajaran Accelerated Learning Berbasis Peta Konsep Terhadap Motivasi Berprestasi dan Hasil Belajar IPS. e-Journal Program Pascasarjana Universitas Pendidikan Ganesha. Volume 3, Nomor 1

Sugiyono. 2013. Statistik Untuk Penelitian. Bandung: Alfabeta.

Sugiyono.2014. Metode Penelitian Administrasi. Bandung: Alfabeta

Surayya,L 2014. "Pengaruh Model Pembelajaran Think Pair Share Terhadap Hasil Belajar IPA Ditinjau Dari Keterampilan Berpikir Kritis Siswa”. Singaraja: Universitas Pendidikan Ganesha.

Susanti, Tati, Budiman Tampubolon, Suhardi Marli. 2017. Pengaruh Model Pembelajaran Think Pair Share Terhadap Hasil Belajar Siswa di Kelas IV Sekolah Dasar. Jurnal Pendidikan dan Pembelajaran. Volume 6 Nomor 3

Susanto,Ahmad. 2013. Teori Belajar dan Pembelajaran di Sekolah Dasar. Jakarta: PrenandaMedia Group

Tas, Sarifa Anthonius Palimbong, dan Hasdin. 2014. Meningkatkan Prestasi Belajar Siswa Melalui Penerapan Model Pembelajaran Kooperatif Tipe Think-Pair Share Alam Pembelajaran IPS di Kelas IV SDN Inpres Mayayap. Jurnal Kreatif Tadulako Online. Volume 4, Nomor 12 (hlm. 115-125)

Trianto. 2015. Mendesain Model Pembelajaran Inovatif, Progresif, dan Kontekstual.Jakarta: Prenadamedia Group.

Trianto. 2014. Model Pembelajaran Terpadu Konsep, Strategi, dan Implementasinya dalam Kurikulum Satuan Tingkat Pendidikan (KTSP). Jakarta: PT. Bumi Aksara

Tristiantari, Ni Ketut Desia, A.A.I.N Marhaeni \& I Wayan Koyan. 2013. Pengaruh Implementasi Model Pembelajaran Kooperatif Tipe TPS Terhadap Kemampuan Berbicara dan Keterampilan Berpikir Kreatif pada Siswa Kelas V SD Negeri Gugus III Kecamatan Seririt. e-Journal Program Pascasarjana Universitas Pendidikan Ganesha. Volume 3, Nomor 1

Usman Samatowa,2016. Pembelajaran Ipa diSekolah Dasar. Jakarta: PT. Indeks

Yulianti, Deviana.2013. "Penerapan Model Contextual Teaching And Learning (CTL) Dengan Metode Eksperimen Dalam Peningkatan Pembelajaran IPA Siswa Kelas IV SD”. (Tidak diterbitkan). PGSD FKIP Universitas Sebelas Maret Kampus Kebumen. 